\title{
Therapy of Canine Deep Pyoderma with Cephalexins and Immunomodulators
}

\author{
F. ŠPRUČEK ${ }^{1}$, M. SVOBODA ${ }^{2}$, M. TOMAN ${ }^{2,3}$, M. FALDYNA ${ }^{2,3}$ F. ŠPRUČEK Jr ${ }^{1}$. \\ ${ }^{1}$ Small Animal Clinic, Olomouc, Czech Republic \\ ${ }^{2}$ Veterinary Research Institute, Brno, Czech Republic \\ ${ }^{3}$ Department of Microbiology and Immunology, Faculty of Veterinary Medicine, \\ University of Veterinary and Pharmaceutical Sciences, Brno, Czech Republic
}

Received January 28, 2007

Accepted July 9, 2007

\begin{abstract}
Špruček F., M. Svoboda, M. Toman, M, Faldyna F. Špruček Jr: Therapy of Canine Deep Pyoderma with Cephalexins and Immunomodulators. Acta Vet. Brno 2007, 76: 469-474.

Pyodermas are among bacterial skin diseases often resisting antibiotic therapy. We therefore examined how the dogs with deep pyoderma $(n=29)$ respond to therapeutic effect of antibiotic cephalexins $\left(\right.$ Ceporex $^{\circledR} 30 \mathrm{mg} \cdot \mathrm{kg}^{-1}$ p.o., once a day for $9-11$ weeks) combined with immunomodulators (Baypamune $^{\circledR}$, once a week i.m. pro toto). The dogs with the first occurrence of pyoderma $(\mathrm{n}=11)$ were treated by antibiotics alone, whereas the dogs with recurrent pyoderma $(n=18)$ were treated by either antibiotics alone $(n=8)$ or antibiotics combined with Baypamune ${ }^{\circledR}(n=10)$. Of 11 dogs with the first occurrence of disease, $8(73 \%)$ were successfully cured. However, only 5 of them $(45 \%)$ stayed recovered after a period of two months that elapsed from the completion of therapy. Of the 8 dogs with recurrent pyoderma treated by antibiotics only, $6(75 \%)$ recovered quickly but only 3 of them $(38 \%)$ stayed healthy after 2 months elapsing from the therapy termination. Of the 10 dogs treated by antibiotics combined with immunomodulators, $8(80 \%)$ regained health within a therapeutic period and 7 of them $(70 \%)$ remained completely cured after 2 months from completion of therapy. The durations of treatment in dogs with the first occurrence of pyoderma and those with recurrent pyoderma were 8.4 and 10.5 weeks, respectively, the difference begin significant. Hair lenght and percentage of the skin area affected had no effect on the therapy duration. The disappearance of pruritus preceded the successful treatment. The results suggest that the joint treatment of deep pyodermas in dogs by antibiotics and immunomodulators may be superior to the purely antibiotic therapy, because of a stronger suppressive effect on the disease relapse.
\end{abstract}

Cephalexin, Baypamune ${ }^{\circledR}$, Staphylococcus intermedius, deep pyoderma

Pyoderma represents a large group of canine skin diseases that are difficult to treat. These are mostly inflammations of secondary nature linked to coagulase-positive Staphylococcus spp. Purulent skin inflammation is not a definitive diagnosis, but only a clinical symptom, which masks the main (primary or secondary) cause of the disease; sometimes several factors can play a role in triggering the disease. A major problem consists in increased pruritus which prevents the skin from healing. Self-mutilation due to the pruritus causes other infective skin changes (Rybníček 1999; Chabanne et al. 2000; De Boer and Marsella 2001; Craig 2003).

Suitable antibiotics may be selected based on experience and observation, especially in case of surface pyoderma after cytological examination of pus and positive bacterial cultivation from an intact pustule. Bacteriological testing and sensitivity to antibiotics must be carried out in case of deep pyoderma, recurrent pyoderma, or if the antibiotic therapy proves to be unsuccessful. Tests may be repeated during the therapy (Scott et al. 2001). Antibiotics with bacteriostatic effect are suitable for superficial pyoderma. Antibiotics with bactericide effect are the drug of choice for cases of recurrent deep pyoderma and for weakened individuals (Lloyd and Grant 1996). Recommended

Address for correspondence:

MVDr. František Špruček, Ph.D.

Small Animal Clinic

Tylova 3, 77900 Olomouc

Czech Republic
Phone:+ 420585226008

Fax: +420585226008

Email: sprucek@email.cz

http://www.vfu.cz/acta-vet/actavet.htm 
Table 1. Survey of orally administered antibiotics and sulfonamides in the treatment of deep pyoderma in dogs in recommended dosage according to individual authors. Administration period is $5-7$ weeks (depending on clinical symptoms)

\begin{tabular}{|c|c|c|c|}
\hline Antibiotic/Sulfonamids & Dose $\left(m g \cdot \mathrm{kg}^{-1}\right)$ & Daily frequency & Authors \\
\hline Amoxycilin & $10-20$ & $\times 2$ & Lloyd and Grant 1996 \\
\hline Oxacilin & 20 & $\times 3$ & Lloyd and Grant 1996 \\
\hline Co-amoxiklav (Synulox $\left.{ }^{\circledR}\right)$ & 12.5 & $\times 2-3$ & Lloyd and Grant 1996 \\
\hline Cephalexin $\left(\right.$ Ceporex $\left.{ }^{\circledR}\right)$ & $15-30$ & $\times 1-2$ & Lloyd and Grant 1996 \\
\hline Cephalexin & 15 & $\times 2$ & Guaguere et al.1998 \\
\hline Cephalexin (Rilexin $®)$ & 15 & $\times 2$ & Mason and Kietzmann 1999 \\
\hline Cephalexin (Rilexin $\left.{ }^{\circledR}\right)$ & 30 & $\times 1$ & Mason and Kietzmann 1999 \\
\hline Cefadroxil (Cafadrox $\left.{ }^{\circledR}\right)$ & 10 & $\times 2$ & Mason and Kietzmann 1999 \\
\hline Enrofloxacin & 5 & $\times 1$ & Ihrke et al. 1999 \\
\hline Enrofloxacin & $10-20$ & $\times 1$ & Hnilica and May 2004 \\
\hline Orbifloxacin & 5 & $\times 1$ & Ihrke et al.1999 \\
\hline Orbifloxacin & 7,5 & $\times 1$ & Hnilica and May 2004 \\
\hline Difloxacin & 5 & $\times 1$ & Ihrke et al. 1999 \\
\hline Marbofloxacin & 2 & $\times 1$ & Ihrke et al. 1999 \\
\hline Marbofloxacin & 5 & $\times 1$ & Hnilica and May 2004 \\
\hline Erytromycin & $10-20$ & $\times 3$ & Hnilica and May 2004 \\
\hline Linkomycin & $15-33$ & $\times 2-3$ & Hnilica and May 2004 \\
\hline Tylosin & 20 & $\times 2$ & Hnilica and May 2004 \\
\hline Clindamycin & 10 & $\times 2$ & Hnilica and May 2004 \\
\hline Rifampicin & $5-10$ & $\times 1$ & Hnilica and May 2004 \\
\hline Ormetoprim + sulfa $^{1}$ & 27.5 & $\times 2$ & Hnilica and May 2004 \\
\hline Trimethoprim + sulfa $^{2}$ & $15-30$ & $\times 1-2$ & Hnilica and May 2004 \\
\hline Baquiloprim + sulfa & 30 & $\times 1$ in 2 days & Hnilica and May 2004 \\
\hline
\end{tabular}

${ }^{1}$ sulfa. - sulfadiazine or sulfametoxazol ${ }^{2}$. When administered for a long period of time and high dosing it may cause hypothyroidism, KCS and bone marrow suppression

doses for individual antibiotic groups according to individual authors are shown in Table 1.

Cephalexin dosed at $15-30 \mathrm{mg} \cdot \mathrm{kg}^{-1}$ p.o. q $12-24 \mathrm{~h}$ has a quick effect, and it also kills staphylococci located on mucosal membranes (Lloyd and Grant 1996). Dosing according to Mason and Kietzmann (1999) is Cefaseptin ${ }^{\circledR} 20 \mathrm{mg} \cdot \mathrm{kg}^{-1}$ p. o.q $8 \mathrm{~h}$, Rilexine ${ }^{\circledR} 15$ $\mathrm{mg} \cdot \mathrm{kg}^{-1}$ p.o.q $24 \mathrm{~h}$ or $30 \mathrm{mg} \cdot \mathrm{kg}^{-1}$ p.o.q $24 \mathrm{~h}$; even this dose was clinically highly effective. Both medications have identical pharmacokinetic profile, but we do not know their action mechanism in such different dosing. Cephalexin $\left(\right.$ Rilexin $\left.^{\circledR}\right)$ dosed at $15 \mathrm{mg} \cdot \mathrm{kg}^{-1}$ p.o. q $12 \mathrm{~h}$ (Guaguere et al. 1998) had the success rate of $92 \%$ of cured dogs in 28 days compared to co-amoxiklav (Synulox ${ }^{\circledR}$ ) dosed at $12.5 \mathrm{mg} \cdot \mathrm{kg}^{-1}$ p. o. q $12 \mathrm{~h}$, with $72 \%$ of cured in 35 days. Synulox $^{\circledR}$ acts more slowly, it is given for a longer period of time and it is less effective (Guaguere et al. 1998). Post-antibiotic effect of cephalexin lasted for $3 \mathrm{~h}$ and $20 \mathrm{~min}$ (Bousquet et al. 1999). In the study dealing with pharmacokinetics of cephalexin after administration of Rilexin ${ }^{\circledR}$ in tabs dosed at $15 \mathrm{mg} \cdot \mathrm{kg}^{-1}$ p.o. $\mathrm{q} 12 \mathrm{~h}$ and Cefaseptin ${ }^{\circledR}$ in coated tablets dosed at $25 \mathrm{mg} \cdot \mathrm{kg}^{-1}$, quick absorption was observed. No significant difference in the pharmacokinetics between both preparations was observed (Ehinger and Kietzmann 2002). 


\section{Materials and Methods}

Twenty nine dogs of various breeds were included in the therapy of deep pyoderma study group (Labrador Retriever, English Bulldog, Golden Retriever, Shar-pei, Bernese Mountain Dog, etc.), the average age of dogs was 6 years (from 2 to 10 years) and sex representation was 13 females and 16 males. Dogs with deep pyoderma $(n=29)$ formed a group $(\mathrm{n}=18)$ with idiopathic recurrent deep pyoderma (they were previously treated with antibiotics, antibiotics combined with glucocorticoids, and glucocorticoids); while another group consisted of dogs $(n=11)$ with the first episode of deep pyoderma, that were never treated before. According to the therapy method, 29 dogs with deep pyoderma were divided into three groups. The first group of dogs with recurrent deep pyoderma $(n=10)$ received cephalexin $\left(\right.$ Ceporex $\left.^{\mathbb{R}}\right)$ dosed at $30 \mathrm{mg} \cdot \mathrm{kg}^{-1}$ p.o. q $24 \mathrm{~h}$ combined with Baypamune ${ }^{\circledR}$ i. m. pro toto, $1 \times$ per week. The second group of dogs with recurrent deep pyoderma $(\mathrm{n}=8)$ received cephalexin $\left(\right.$ Ceporex $\left.^{\mathbb{R}}\right)$ dosed at $30 \mathrm{mg} \cdot \mathrm{kg}^{-1} \mathrm{p} .0 . \mathrm{q} 24 \mathrm{~h}$ and the third group of dogs $(n=11)$ with the first episode of deep pyoderma without previous treatment were also given cephalexin $\left(\right.$ Ceporex $\left.{ }^{\circledR}\right)$ dosed at $30 \mathrm{mg} \cdot \mathrm{kg}^{-1}$ p.o. q $24 \mathrm{~h}$. The treatment length ranged between $9-11$ weeks. Their health status was continuously monitored. The group of dogs with i. m. administration of Baypamune ${ }^{\circledR}$ was checked once per week, while other groups once per two weeks. In our study of 29 tested dogs with deep pyoderma, we bacteriologically examined $(\mathrm{n}=10)$ randomly selected dogs.

\section{Statistical analysis}

Dogs with deep pyoderma were tested with t-test, amended with the test of equality of variances of compared selections. If the selection variances were not equal, the Welch's analysis of variance was used as a significance test. Percentage differences were tested with Wilcoxon's non-parametric test. If the variances were unequal (heteroskedasticity), we again used the Welch's modification of variance analysis. The relation between two quantitative variables was analyzed using the linear regression method. We used the JMP program (SAS Institute Inc. 2005) for all statistical examinations.

\section{Results}

From the total number of 29 dogs with deep pyoderma, 22 animals were cured at the end of therapy $(76 \%)$, and after two months the success rate of the therapy decreased due to recurrence, to 15 patients (52\%). In individual groups of dogs divided according to therapy, the situation was as follows: after two months from the end of therapy, there were relapses in three cases in the group of dogs $(n=11)$ with the first episode of the disease and treated with antibiotics Cephalexin (Ceporex $30 \mathrm{mg} \cdot \mathrm{kg}^{-1}$ p.o. q $24 \mathrm{~h}$ for 9 - 11 weeks), so the relative number of cured dogs decreased from $73 \%$ to $45 \%$ (Fig. 1).

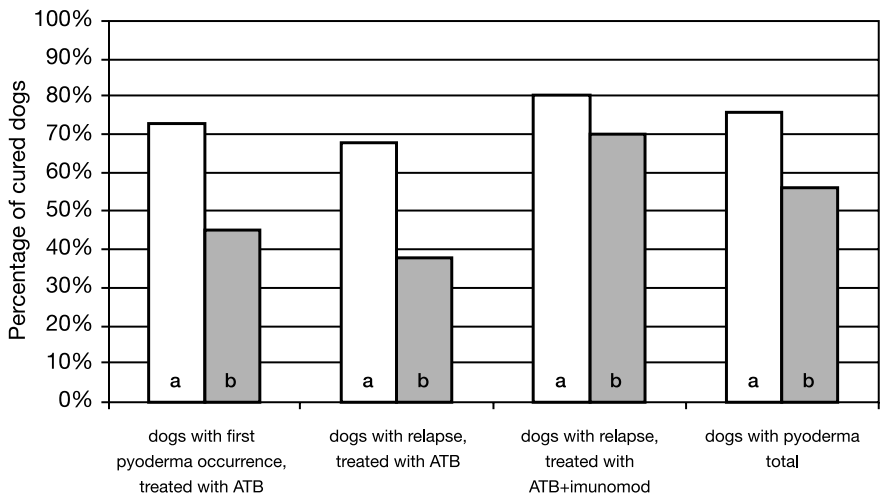

Fig. 1. a) Relative values for cured dogs with deep pyoderma after the end of therapy

b) Relative values for cured dogs in 2 months from the end of treatment, decreased due to relapse during the monitored period. Dogs treated for the first time with ATB $(n=11)$, dogs with relapse treated with ATB $(n=$ $8)$, dogs with relapse treated with ATB combined with immunomodulators $(n=10)$, dogs treated with deep pyoderma total $(\mathrm{n}=29)$

In the group of dogs $(n=8)$ with relapses, treated also with antibiotics cephalexin $\left(\right.$ Ceporex $^{\circledR} 30 \mathrm{mg} \cdot \mathrm{kg}^{-1}$ p.o., $1 \times$ per day for 9 - 11 weeks) there were three recurrent cases, the relative number of cured dogs decreased from $75 \%$ to $38 \%$. One relapse was recorded in 
the group of dogs $(n=10)$ with recurrent pyoderma treated with antibiotics combined with immunomodulators cephalexin (Cepore ${ }^{\circledR}$ dosed at $30 \mathrm{mg} \cdot \mathrm{kg}^{-1}$ p.o. q $24 \mathrm{~h}$ in combination with Baypamune ${ }^{\circledR}$ i. m. pro toto, $1 \times$ per week), where the relative number of cured dogs decreased from $80 \%$ to $70 \%$ (Table 2 ).

Table 2. Overview of absolute and relative numbers of treated and cured dogs with deep pyoderma after the end of treatment and relapses after 2 months

\begin{tabular}{|l|c|c|c|c|}
\hline Parameters & $\begin{array}{c}\text { Dogs treated } \\
\text { for the first } \\
\text { time } \\
\text { Cephalexin } \\
\text { cured/abs. }^{1}\end{array}$ & $\begin{array}{c}\text { Dogs } \\
\text { with relapse } \\
\text { Cephalexin } \\
\text { cured/abs. }\end{array}$ & $\begin{array}{c}\text { Dogs with relapse } \\
\text { Cephalexin+Baypamune } \\
\text { cured/abs. }\end{array}$ & $\begin{array}{c}\text { Total number } \\
\text { of dogs } \\
\text { with pyoderm } \\
\text { a cured/abs. }\end{array}$ \\
\hline Cured in 9-11 weeks & $8 / 11(73 \%)$ & $6 / 8(75 \%)$ & $8 / 10(80 \%)$ & $22 / 29(76 \%)$ \\
\hline Relapse after 2 months & $3 / 11(27 \%)$ & $3 / 8(38 \%)$ & $1 / 10(10 \%)$ & $7 / 29(24 \%)$ \\
\hline $\begin{array}{l}\text { Cured dogs with } \\
\text { pyoderma in 2 months total }\end{array}$ & $5 / 11(45 \%)$ & $3 / 8(38 \%)$ & $7 / 10(70 \%)$ & $15 / 29(52 \%)$ \\
\hline
\end{tabular}

${ }^{1}$ cured / abs. - absolute numbers of cured dogs with deep pyoderma / from the total number of dogs in the group

The success rate of the therapy of dogs with recurrent deep pyoderma $(n=18)$, treated with antibiotics cephalexin $\left(\right.$ Ceporex $^{\circledR} 30 \mathrm{mg} \cdot \mathrm{kg}^{-1}$ p.o. q $24 \mathrm{~h}$ ) and antibiotics in combination with immunomodulators (Baypamune ${ }^{\circledR} 1 \times$ per week i. m.) increased by $56 \%$ compared to the previous treatment with antibiotics (Synulox ${ }^{\circledR} 12.5 \mathrm{mg} \cdot \mathrm{kg}^{-1}$ p.o. q $12 \mathrm{~h}$ ) and glucocorticoids (Prednison $2 \mathrm{mg} \cdot \mathrm{kg}^{-1}$ p.o. q $24 \mathrm{~h}$ ). After the end of therapy, we had an $80 \%$ (i.e. 8 cured of $10 \mathrm{dogs})$ success rate in $\operatorname{dogs}(n=10)$ treated with antibiotic in combination with immunomodulators, in contrast to the group of dogs treated with antibiotics only $(n=19)$, where the success rate of the therapy was $70 \%$ (i.e. 14 cured of 19 dogs). After two months, the success rate of the therapy in the group of dogs treated with antibiotics and immunomodulators decreased due to relapse to $70 \%$ (i.e. 7 of $10 \mathrm{dogs}$ ), and in dogs treated with antibiotics only there was a significant decrease in the therapy success rate due to relapse to $41 \%$ (i.e. 8 cured of 19 dogs).

The average length of therapy with antibiotics and antibiotics in combination with immunomodulators was 9.6 weeks. Differences in the length of therapy between sexes were not found ( $t$-test males 9.8 weeks, females 9.4 weeks, $P=0.51)$. Hair length and the percentage of affected skin surface had no effect on the length of treatment $(P=0.79)$, and neither did animal weight $(P=0.19)$. Dogs with recurrent deep pyoderma $(n=18)$ healed 14 days longer than the patients with the first episode of the disease $(n=11)$, treated only with cephalexin. In dogs with relapse, the treatment period was 10.5 weeks and in dogs with the first episode of the disease it was 8.4 weeks $(P<0.001)$. The period of pruritus resolution had a significant predictive effect on the total length of treatment (Fig. 2). Earlier disappearance of pruritus indicated shorter treatment $(P=0.004)$. No significant relation between age and length of treatment was established $(P=0.64)$.

In our study of 29 tested dogs with deep pyoderma, we randomly chose 10 dogs for bacteriological examination. In $(\mathrm{n}=7)$ dogs we diagnosed Staphylococcus intermedius (70\%), one E. coli, Streptococcus spp. and Actinomyces spp.

\section{Discussion}

Available studies on pharmacokinetics of cephalexin after oral administration (Rilexin ${ }^{\circledR}$ dosed at $15 \mathrm{mg} \cdot \mathrm{kg}^{-1}$ p.o. q $12 \mathrm{~h}$ in tablets and Cefaseptin ${ }^{\circledR}$ in coated tablets in the dose of $25 \mathrm{mg} \cdot \mathrm{kg}^{-1}$ ) observed rapid absorption in the affected tissue. Maximum concentration in 


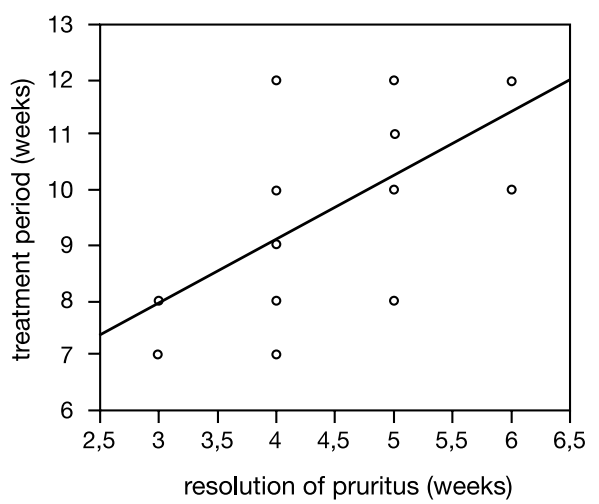

Fig. 2. Dependence between treatment period in weeks and the resolution of clinical symptoms of pruritus in dogs treated with deep pyoderma

plasma was achieved in $1.5 \mathrm{~h}$ after administration (Ehinger and Kietzmann 2002). No visible difference in the pharmacokinetics of both preparations was determined (Ehinger and Kietzmann 2002). In our study, we used cephalexin in Ceporex ${ }^{\circledR} 30 \mathrm{mg} \cdot \mathrm{kg}^{-1}$ p.o. q $24 \mathrm{~h}$ for 9 - 11 weeks (Guaguere et al. 1998). This dosage, compared to $15 \mathrm{mg} \cdot \mathrm{kg}^{-1}$ p.o. q $12 \mathrm{~h}$, reportedly has a similar therapeutic effect and administration of the preparation $\times 1$ per day is more convenient for the animal owners.

Baypamune $^{\circledR}$ activates NK (natural killer) cells, stimulates lymphocytic proliferation, and activates macrophages and production of interleukins and antiviral interferon. Baypamune $^{\circledR}$ is suitable for modulation of non-specific immunity reaction and to stimulate suppressed immunity after the end of administration of immunosuppressive doses of steroids (Winnicka et al. 2000).

In the clinical study dealing with dogs with deep pyoderma, Baypamune ${ }^{\circledR}$ was administered simultaneously with antibiotics cephalexin (Ceporex $\left.{ }^{\circledR}\right)$ in all cases of recurrent deep pyoderma that were previously treated with antibiotics and steroids. After the end of therapy, no significant difference was observed in the success rate of treatment between the group treated with antibiotics and immunomodulators - $80 \%$ (i.e. 8 of $10 \mathrm{dogs}$ ), and the group treated with antibiotics only - 70\% (i.e. 14 of 19 dogs). In dogs with deep pyoderma whose clinical status during treatment did not improve, the primary cause might have been an autoimmune disease. After two months, the success rate of therapy in the group of dogs treated with antibiotics and immunomodulators decreased due to relapse to $70 \%$ (i.e. 7 of $10 \mathrm{dogs}$ ) and in dogs treated only with antibiotics to $41 \%$ (i.e. 8 of 19 dogs). Significant decreasing of the number of recurrent cases indicates a positive effect of immunomodulators on the long-term stabilization of immunity status, which may be partly responsible for the resulting clinical condition. Shorter treatment in dogs treated with antibiotics combined with immunomodulators, as quoted by Winiarzcyk et al. (1998) in his studies, was not observed. The success rate of the therapy in dogs with relapse treated with antibiotics and antibiotics in combination with immunomodulators increased by over $50 \%$ compared to the previous treatment with antibiotics and glucocorticoids, and in dogs with relapse that were treated with antibiotics and immunomodulators it was successful in over $70 \%$. This result indicates a good choice of antibiotics (dosage and period of administration) and the effect of immunomodulator on clinical improvement.

Dogs with recurrent deep pyoderma were treated 14 days longer than patients with the first episode of deep pyoderma. There was a significant decrease in the number of relapses in affected dogs that received Baypamune ${ }^{\circledR}$ combined with cephalexin $\left(\right.$ Ceporex $\left.^{\circledR}\right)$. This combination and the effect of Baypamune ${ }^{\circledR}$ confirms the immunomodulation effect as it 
has been reported after intravenous administration of immunoglobulins, which suppress inflammatory reaction mediated by the complement, activate counter-inflammatory cytokines, affect the activity of endothelial cells, neutralize microbial toxins and decrease requirements for corticosteroids (Foster 2004). Due to difficult diagnostics of primary causes of deep pyoderma and inconsistent etiology, immunomodulation therapy in autoimmune diseases may cause (contrary to immunodeficiencies) adverse effects with subsequent clinical worsening of the overall health condition, leading to relapse.

\section{Terapie hlubokých pyodermií psů cefalexiny a imunomodulátory}

Z 29 psů bylo s prvním výskytem hluboké pyodermie léčeno $(\mathrm{n}=11)$ antibiotiky cefalexiny (Ceporex ${ }^{\circledR} 30 \mathrm{mg} \cdot \mathrm{kg}^{-1}$ p.o., $1 \times$ denně $9-11$ týdnů) s úspěšností $73 \%$. Po dvou měsících po ukončení léčby došlo $\mathrm{k}$ recidivě a relativní počet vyléčených se snížil na $45 \%$. 18 psů s recidivující pyodermií, $\mathrm{z}$ toho $(\mathrm{n}=8)$ bylo léčeno antibiotiky, relativní počet vyléčených psů se snížil z $75 \%$ na $38 \%$ a $(\mathrm{n}=10)$ bylo léčeno antibiotiky v kombinaci $\mathrm{s}$ imunomodulátory $\left(\right.$ Cepore $^{\circledR} \mathrm{v}$ kombinaci $\mathrm{s}$ Baypamune ${ }^{\circledR}$ aplikovaný $1 \times$ týdně i.m. (9-11 týdnů), relativní počet vyléčených psů se snížil z $80 \%$ na $70 \%$. U psů s recidivou $(\mathrm{n}=18)$ byla délka léčby 10,5 týdne a u psů $(n=11)$ s prvním výskytem onemocnění 8.4 týdne $(P<0.001)$. Nebyly zjištěny rozdíly v délce léčby mezi samci (9.8 týdne) a samicemi $(9.4$ týdne $),(P=0.51)$. Délka srsti a procento postižené plochy kůže $(P=0.79)$ stejně jako hmotnost zviŕrete $(P=0.19)$ a věk $(P=0.64)$ neměl vliv na délku léčby. Psi s rekurentní hlubokou pyodermií se uzdravovali o 14 dní později než pacienti s prvním výskytem onemocnění $(\mathrm{n}=11)$. Dř́ívější vymizení pruritu indikovalo kratší dobu léčby $(P=0.004)$. Výrazná byla úspěšnost $v$ terapii imunomodulátory $\left(\right.$ Baypamune $\left.{ }^{\circledR}\right)$ v kombinaci s antibiotiky $\left(\right.$ Ceporex $\left.^{\circledR}\right)$ a to především v signifikantním snížení relativního počtu recidiv u skupiny psů s rekurentní hlubokou pyodermií

\section{Acknowledgement}

We thank Emil Tkadlec and Dan Špruček for help with statistical analysis of data.

\section{References}

BOUSQUET E, GANIERE JP, RUVOEN N, LARRAT M 1999: Post-antibiotic effect of cephalexin against isolates of Staphylococcus intermedius obtained from cases of canine pyoderma. Vet Dermatol 10: 253-255

CRAIG M 2003: Diagnosis and management of pyoderma in the dog. In: Practice 25: 418

DEBOER DJ, MARSELLA R 2001: The ACVD task on canine atopic dermatitis (XII): the relationship of cutaneous infections to the pathogenesis and clinical course of canine atopic dermatitis. Vet Immunol Immunopathol 81: 239-249

EHINGER AM, KIETZMANN M 2002: Pharmacokinetics of cephalexin from two oral formulations in dog. Berl und Munch Tierarztl Wochenschrift 115: 57-61

FOSTER AP 2004: Immunomodulation and immunodeficiency. Vet Dermatol 15: 115-126

GUAGUERE R, SALOMON C, MAYNAYRD L 1998: Using cephalexin in the treatment of canine pyoderma. Comparing the Efficacy of Different Posologies. Prat Méd Chir Anim Cie 33: 237-246

CHABANNE L, BONNEFONT C, BERNAUD J, RIGAL D 2000: Clinical applications of flow cytometry and cell immunophenotyping to companion animals (dog and cat). Meth Cell Sci 22: 199-207

LLOYD D, GRANT D 1996: Hluboké pyodermie. 1. ročník Dermatologický kurz ESAVS (29. 11. - 1. 12.1996) Brno, Česká republika

MASON IS, KIETZMANN M 1999: Cephalosporins - pharmacological basis of clinical use in veterinary dermatology. Vet Dermatol 10: 187-192

RYBNÍČEK J 1999: Využití antimikrobiálních látek v dermatologii. Zásady racionální antimikrobiální terapie u psa a kočky, Sborník ze semináře pořádaného ČAVLMZ. Vydalo NOVIKO, a. s. 25-29

SAS Institute Inc. 2005: Statistics and Graphics Guide. Release 6. SAS Campus Drive, Cary, NC, USA

SCOTT DW, MILLER WH, GRIFFIN CE 2001: In: Small Animal Dermatology. 6th Ed., W. B. Saunders, Philadelphia, 2001, pp. 230-232, 274-335, and 647-650

WINIARCZYK P, POMORKSI Z, BLIMKE Z, SITKOWSKI W, TASZKUN I, ZALEWSKI A 1998: Baypamun in the treatment of clinical upper respiratory tract infections in dogs. Med Wet 54: 533-536

WINNICKAA, KLUCINSKI W, KAWIAK J, HOSER G, SIKORA J 2000: Effect of Baypamune ${ }^{\circledR}$ on blood leucocytes in normal and dexamethasone treated goats. J Vet Med Series and - Physiol Pathol Clin Med 46: 385-39 